\title{
Mozgásvizsgálat fényképekból
}

\author{
SIKI Zoltán - TAKÁCS Bence
}

DOI: $10.30921 / G K .73 .2021 .3 .4$

Absztrakt: A geodéziai mozgás- és deformációvizsgálatok területén a fotogrammetria egy újszerú alkalmazását mutatjuk be ebben a cikkben. A fénykép, illetve videó elvételek készitése során Raspberry Pi számitógépet és kamerát alkalmazunk úgy, hogy a kamerát egy geodéziai távcsöre szereljük a felbontás növelése érdekében. A képek feldolgozását teljesen automatizáltuk a nyílt forráskódú Ulyxes-rendszer továbbfejlesztésével. Az automatizálást az úgynevezett ArUco-jelek és az OpenCV-könyvtár segítségével valósítottuk meg. Kétféle algoritmust, egyrészt a sablonillesztést (template matching), másrészt az alakfelismerést is implementáltunk. A sablonillesztés esetén a jel nem fordulhat el és a mérete sem változhat meg, így a képsíkban a jel önmagával párhuzamos elmozdulását tudjuk detektálni. Az alakfelismerés esetén nincsenek ilyen korlátozások. A rendszert dinamikus próbaterhelések során alkalmaztuk, ahol a robot-méróállomások nem elég gyorsak, a GNSS-technika pedig nem elég pontos.

Abstract: In geodetic movement and deformation analysis, a novel application of photogrammetry is presented in this article. The resolution of the images is increased by inserting a geodetic telescope in front of the camera. Raspberry $P i$ computer and camera are used to take photos and videos. Extending the open-source Ulyxes system, image processing was fully automated using the so-called ArUco codes and the OpenCV library. Two different algorithms, namely template matching as well as pattern recognition were implemented. In the case of template matching, the markers cannot be rotated or scaled; therefore, we can detect their parallel displacement in the image plane. On the other hand, though, in the case of pattern recognition, there are no such restrictions. The system was applied during dynamic test loads where the robotic total stations are not fast enough and the GNSS technique is not accurate enough.

Kulcsszavak: mozgásvizsgálat, deformációvizsgálat, képfeldolgozás, nyílt forráskód, Raspberry Pi Keywords: movement analysis, deformation analysis, image processing, open source, Raspberry Pi

\section{Bevezetés}

A cikk a 2020. évi Mérnökgeodézia Konferencián elhangzott előadás írásos változata.

A BME Általános és Felsôgeodézia Tanszékén múködő, a nemzetközi Geo4All (https://www.osgeo.org/ initiatives/geo-for-all/) hálózat tagjai között szereplő OSGeoLabBp laboratóriumban (lásd: http://osgeolabbp. hu) nem csak oktató tevékenységet folytatunk, hanem kutatási és fejlesztési feladatokat is megoldunk nyílt forráskódú szoftverek segítségével. A saját fejlesztések közül kiemelkedik az Ulyxes-rendszer (Siki et al. 2018), amely automatizált adatgyújtést valósít meg különböző geodéziai szenzorok esetén (pl. robot-méróállomás, GNSS-vevô). Jelen cikkünkben a rendszer képfeldolgozás irányában történô bôvítését és annak mozgásvizsgálati alkalmazását mutatjuk be. Az Ulyxesrendszert a kutatás-fejlesztés mellett az oktatásban és ipari alkalmazások során is használjuk. A fényképekből történô mozgásvizsgálatnak hosszú története van, már az Erzsébet híd 1964. évi próbaterhelésénél is alkalmazták a fotogrammetriát a BME munkatársai (Kis
Papp 1965). Az Ulyxes-rendszer elsô ilyen alkalmazása 2015-ben történt a Rákóczi híd dinamikus próbaterhelése során (Kovács et al. 2016). Azóta a hardver és a szoftver területén is fejlesztéseket hajtottunk végre, melyekrôl ebben a cikkben számolunk be. Emellett egy gyakorlati alkalmazást is bemutatunk.

\section{Technikai háttér}

A nyílt forráskódú szoftverfejlesztések egyik elôremutató jó tulajdonsága, hogy más, szintén nyílt forráskódú fejlesztések eredményei közvetlenül felhasználhatóak, ami az egymással versengó kereskedelmi szoftverek esetén elképzelhetetlen. A képfeldolgozás területén egyik elterjedt nyílt forráskódú programkönyvtár az OpenCV (Villán 2019). Ezt elsôsorban a robotlátás támogatására fejlesztették ki, de számos geodéziai és fotogrammetriai alkalmazása is van (pl.: Paulik et al. 2018 vagy EngelSchweimler 2016).
A mozgás-, illetve deformációvizsgálatoknál abból indulunk ki, hogy egy mozdulatlan kamerával készítünk kép- vagy videófelvételeket. A mozgás vagy deformáció nagyságára a képen bekövetkezett változások alapján következtetünk. A képek terepi felbontását egy geodéziai távcsó közbeiktatásával növeljük, mivel a mozgó létesítmény közvetlen közelében nehezen biztosítható a kamera mozdulatlansága, illetve így a terepi pixelméretet is növelni tudjuk. A kamera vezérlésére és a képek, videófelvételek tárolására Raspberry Pi számítógépet használunk. A 8 megapixeles

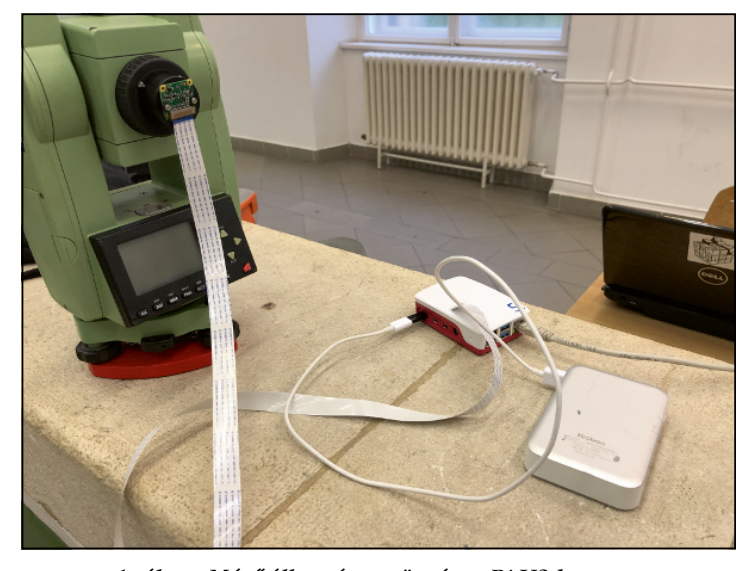

1. ábra. Mérôállomásra rögzített Pi V2 kamera 
Raspberry Pi Camera V2 modult egy speciális elemmel rögzítjük a múszer okulárjára (1. ábra). A Raspberri Pi számítógép energiafogyasztása alacsony, így egy nagyobb teljesítményú power bankkel akár 24 óránál többet is múködhet. WIFI-n keresztül mobiltelefonnal, tablettel vagy laptoppal csatlakozhatunk a Raspbian (Linux) operációs rendszer felügyelete alatt múködô Raspberry Pi számítógéphez. A programok más típusú kamerával és nagyobb teljesítményú számítógéppel is használhatók.

A képfeldolgozás területén széles körben használt algoritmusok közül kettőt is alkalmaztunk a képrészletek elmozdulásának kimutatására. A sablonkeresés (template matching) esetén egy képrészlet elôfordulását keressük egy másik képben. A másik módszer az alakfelismerésre támaszkodva speciális jel (ArUco-kód) előfordulását keresi a képben. A mozgás vagy deformáció nagyságát az egymás után következô képeken a minta vagy jel pozíciójának megváltozásából vezetjük le. A videófelvételek feldolgozása során képkockánként végezzük el a minta vagy jel keresését. Mindkét módszer esetén célszerú a színes képeket szürke árnyalatos képpé átalakítani a feldolgozás elốtt, így gyorsítani tudjuk az algoritmusok futását.

\section{Sablonkeresés}

A módszer alapgondolata az, hogy egy képrészlet előfordulását megkeressük a képfelvételeinken. A képrészlet legvalószínúbb helyének megkereséséhez minden kombinációban ráillesztjük a részletet, és képpontonként vizsgáljuk az egymás fölé kerülő pixelek eltérését. Az eltérésekbôl egy összeget állítunk elô minden pozícióra, ami az illeszkedést jellemzi. Több különbözô függvényt alkalmaznak a gyakorlatban, ezek szélsôértéke jelenti a legjobb egyezést. Az OpenCV-könyvtár ehhez hat különböző függvényt biztosít (OpenCV Tutorials, é. n.). Ezek közül a normalizált keresztkorreláció (cross correlation) (BriechleHanebeck 2001) (1), illetve a normalizált korrelációs együttható (correlation coefficient) (2) bizonyult a legmegbízhatóbbnak a gyakorlati alkalmazásaink során.
$R(x, y)=\frac{\sum_{x^{\prime}, y^{\prime}}\left(T\left(x^{\prime}, y^{\prime}\right) \cdot I\left(x+x^{\prime}, y+y^{\prime}\right)\right)}{\sqrt{\sum_{x^{\prime}, y^{\prime}} T\left(x^{\prime}, y^{\prime}\right)^{2} \cdot \sum_{x^{\prime}, y^{\prime}} I\left(x+x^{\prime}, y+y^{\prime}\right)^{2}}}$

Ahol:

$x^{\prime}, y^{\prime}$ - oszlop- és sorpozíció a keresett mintában

$x, y$ - oszlop- és sorpozíció a vizsgált képben

$T\left(x^{\prime}, y^{\prime}\right)$ - pixelérték a keresett minta-pozícióban

$l\left(x+x^{\prime}, y^{+} y^{\prime}\right)$ - pixelérték a vizsgált képben

$R(x, y)=\frac{\sum_{x^{\prime}, y^{\prime}}\left(T^{\prime}\left(x^{\prime}, y^{\prime}\right) \cdot I^{\prime}\left(x+x^{\prime}, y+y^{\prime}\right)\right)}{\sqrt{\sum_{x^{\prime}, y^{\prime}} T^{\prime}\left(x^{\prime}, y^{\prime}\right)^{2} \cdot \sum_{x^{\prime}, y^{\prime}} I^{\prime}\left(x+x^{\prime}, y+y^{\prime}\right)^{2}}}$

Ahol:

$$
\begin{aligned}
& T^{\prime}\left(x^{\prime}, y^{\prime}\right)=T\left(x^{\prime}, y^{\prime}\right)-\frac{1}{w^{\prime} \cdot \boldsymbol{h}} \cdot \sum_{x, y} T(x, y) \\
& I^{\prime}\left(x+x^{\prime}, y+y^{\prime}\right)=I\left(x+x^{\prime}, y+y^{\prime}\right)-\frac{1}{w^{\prime} \cdot \boldsymbol{h}} \cdot \sum_{x, y} I(x+x, \mathbf{y}+\mathbf{y})
\end{aligned}
$$

$w$ - a keresett minta szélessége pixelekben

$\boldsymbol{h}$ - a keresett minta magassága pixelekben

A normalizált összefüggés eredménye nulla és egy közé esik, az egy érték jelenti a tökéletes egyezést. Így az eredményból közvetlenül következtethetünk az egyezés minőségére. A mozgásvizsgálatok során hosszabb ideig is eltarthat a felvételek készítése, melyek során nem lehet biztosítani az azonos körülményeket (fényviszonyok, pára stb.) ezért az egyezés minôsége széles tartományban változhat. A 2. ábrán a jobb oldalon alul a normalizált korrelációs együttható eredményeit szürke árnyalatossá alakítottuk át, a fehér szín a legjobb, a fekete szín a legrosszabb illeszkedést jelenti. A sablonkeresés feltételezi, hogy a minta csak önmagával párhuzamosan mozdul el a képen, és a mérete sem változik.

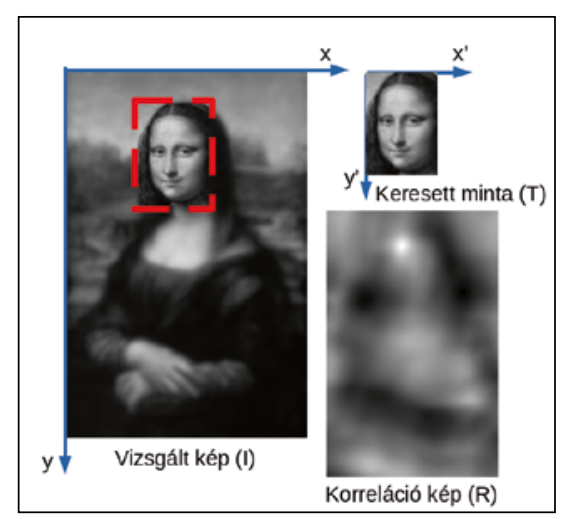

2. ábra. A sablonkeresés eredménye

\section{ArUco-kódok keresése}

Az ArUco-kódok speciális négyzet alakú sakktáblaszerú jelek, melyeket fekete keret vesz körül, különböző felosztású változatai léteznek a 4×4-tôl a 7×7-ig (3. ábra). Az egyes jelek egy egész számot jelképeznek. Elsôsorban a kiterjesztett valóság alkalmazásokhoz fejlesztették ki, a szoftver a képben megtalált ArUco-kód helyén más tartalmat jelenít meg. Emellett alkalmazzák beltéri navigációban, amikor a kódérték alapján egy jel koordinátája kereshetố vissza, illetve a fotogrammetriában, ahol az ArUco-kóddal jelölt illesztôpontok automatizáltan visszakereshetók a képen. A fotogrammetriai alkalmazáshoz laborunkban is készítettünk nyílt forráskódú megoldást (lásd: https://github.com/zsiki/ Find-GCP) az ODM-(Open Drone Map https://www.opendronemap.org) és VisualSfM- (http://ccwu.me/vsfm) szoftverekhez.

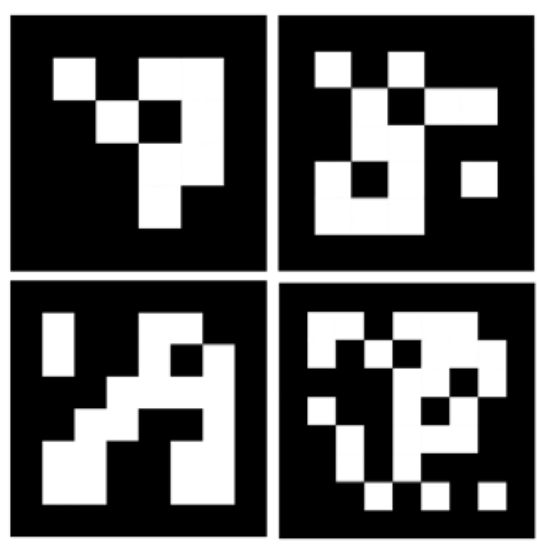

3. ábra. $4 \times 4,5 \times 5,6 \times 6$ és $7 \times 7$ ArUco-kódok

Az ArUco-kódok alkalmazása esetén a kód tetszőleges méretû, elfordult és perspektíven torzult képét próbáljuk megkeresni. Ehhez jóval összetettebb algoritmus szükséges (4. ábra), a sablonkereséshez képest, amely számos paraméter megadásával hangolható és finomítható. Az elsô lépésben a képet szürke árnyalatossá konvertáljuk, majd adaptív küszöbértékek alkalmazásával kétszínúre egyszerúsítjük. Az adaptív küszöbérték azt jelenti, hogy nem az egész képre egységesen megadott küszöb alapján döntjük el, hogy ez egyes képpontok fehér vagy fekete színúek legyenek, hanem a képet kisebb egységekre bontva végezzük el ezt. Ez lehetôvé teszi, hogy a 


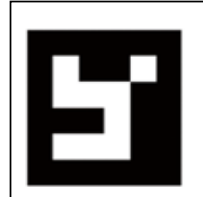

Eredeti jel
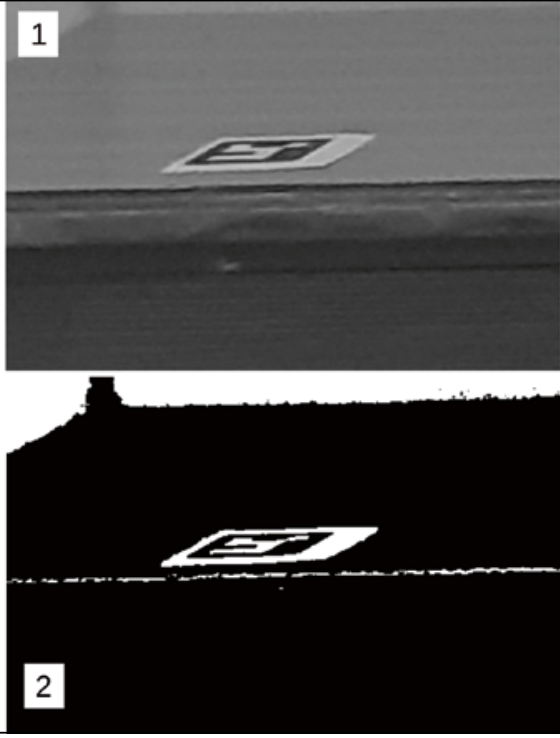

4. ábra. ArUco-jel-felismerés folyamata
3

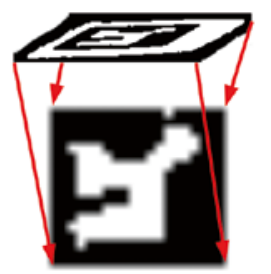

4

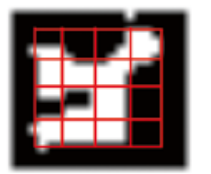

0001

1110

0010

1110 fényviszonyoktól, az esetleges árnyékoktól függetlenül a fekete-fehér képen jól felismerhetô legyen a jel. A második lépésben a képen az egyenesekkel határolt zárt négyszögeket keressük meg. A harmadik lépésben a perspektív torzulás hatását küszöböljük ki, a négyszöget négyzetté transzformáljuk. Végül a negyedik lépésben egy rácsot illesztünk a jelre, hogy 0 vagy 1 értékeket rendeljünk az egyes cellákhoz. A feldolgozáshoz megadható paraméterek segítségével az egyes lépések során szúréseket végzünk, például a négyszög méretére (OpenCV Tutorials, é. n.).

Az ArUco-kódok kezelését az OpenCV-könyvtár egy önálló bôvítménye tartalmazza, mely a felismerés mellett lehetôséget biztosít a jelek elôállítására a kinyomtatáshoz és a kamerakalibrációra.

A két bemutatott módszer összehasonlítását az 1. táblázat tartalmazza. Általánosságban elmondható az is, hogy az OpenCV-könyvtár által biztosított megoldások esetén a sablonkeresés több idốt vesz igénybe.

\section{Algoritmusok fejlesztése}

Mind a sablonkeresés, mind az ArUcokód felismerése esetén az OpenCVkönyvtár által biztosított megoldásokat finomítottuk, egyrészt a futási idố csökkentése, másrészt a felismerés eredményességének javítása érdekében.

Az OpenCV által kínált alapalgoritmusok esetén az ArUco-kód keresése kétszer, háromszor gyorsabb mint a sablon illesztés. Mindkét algoritmus alkalmazása során, ha feltételezhetjük azt, hogy a két egymást követô kép között az elmozdulás mértéke kicsi, akkor nem szükséges a következô képet teljeskörúen megvizsgálni a jel megtalálásához. Az előzô képen megtalált minta, jel megnövelt környezetére elvégezve a keresést felgyorsíthatjuk az egyes képek feldolgozását. Ez a sablonkeresés esetén, az elôzô képen megtalált jel négyszeresére korlátozott kereséssel akár egy nagyságrenddel gyorsíthatjuk a feldolgozást, természetesen a sebességnövekedés
A sablonkeresés és ArUco-kód-keresés összehasonlítása

\begin{tabular}{|l|l|}
\hline Sablonkeresés & ArUco-kód-felismerés \\
\hline \multicolumn{2}{|c|}{ Elônyök: } \\
\hline Mindig van találat & A jel elfordulhat \\
\hline Egyszerű algoritmus & A jel mérete változhat \\
\hline Nem szükséges jeleket előre elhelyezni & A normális irány is becsülhetô \\
\hline \multicolumn{2}{|c|}{ Hátrányok: } \\
\hline Hamis találat esélye nagyobb & Fényviszonyokra érzékenyebb \\
\hline Csak minimális elfordulás lehet & Speciális jelet kell előre elhelyezni \\
\hline Csak minimális méretváltozás lehet & Nincs mindig találat, hamis találat is lehet \\
\hline
\end{tabular}

nagymértékben függ a kép és a keresett minta területének arányától. Az ArUco-kód felismerése esetén nem jár különösebb hatékonyságnövekedéssel a kisebb részletre korlátozott feldolgozás.

A gyakorlati alkalmazás során a szabadtéren, ahol a fényviszonyok sokat változhatnak a felvételek elkészítése során, nehézségekbe ütközhetünk elsôsorban az ArUco-kódok felismerése során. Az 5. ábrán a napsugarak tükrözôdése miatt a program nem képes az ArUco-jelet felismerni. Ezen a kép színtartományának a széthúzásával segíthetünk. A leghatékonyabb megoldást a CIELAB-színtérbe (Simonot et al. 2011) konvertálással kaptuk. Ez az L*a*b* hivatkozással is bíró színtér az RGB- vagy HSV- színkódokhoz hasonlóan bármely szín leírására alkalmas. A L* komponens az érzékelt fényességet, az a* és $b^{*}$ a vörös, zöld, kék és sárga színösszetevőket írja le. Az RGB-képet az L*a*b* színtérbe konvertálva az L* csatornát használjuk csak, amelyre egy adaptívhisztogram-kiegyenlítést alkalmazunk és ennek eredményeképpen kialakult szürke árnyalatos képet használjuk a továbbiakban. A 2. táblázat adatai alapján 5-40 százalékkal sikerült megnövelni az ArUco-kódok megtalálásának arányát.

A két optikai rendszer, a geodéziai távcsố és a Raspberry Pi V2 kamera, együttesen nem elhanyagolható párnás elrajzolást eredményez (6. ábra). Ezért a kamera és a geodéziai távcsô együttes kalibrálására van szükség (Völgyesi-Tóth 2020). Az OpenCV alapsakktáblás kalibrálása mellett az ArUco-könyvtár két további kalibrálási eljárást biztosít, a ChArUcotáblásat és az ArUco-táblásat. Ez utóbbi két módszer esetén a tábla kisebb takarása vagy egy részének kilógása nem hiúsítja meg a kép használatát a kalibrációban, emellett a táblán megjelenô ArUco-kódok pontosabbá teszik a kalibrációt.

A kalibráció során a tábláról több különbözô szögbôl készült felvétel alapján a kamera mátrix $\left(\mathrm{f}_{\mathrm{x}}, \mathrm{f}_{\mathrm{y}}, \mathrm{c}_{\mathrm{x}}\right.$, $\left.c_{\mathrm{v}}\right)$, valamint a radiális $\left(\mathrm{k}_{1}, \mathrm{k}_{2}, \mathrm{k}_{3}\right)$ és tangenciális $\left(\mathrm{p}_{1}, \mathrm{p}_{2}\right)$ torzítási paramétereinek meghatározása történik meg. 

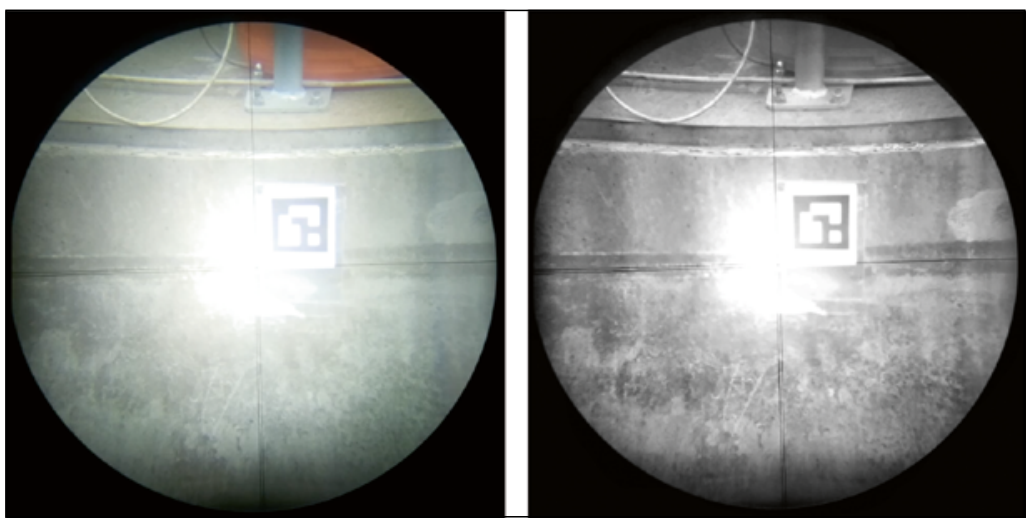

5. ábra. Az eredeti kép (bal oldal) és

az adaptivisztogram-kiegyenlités eredménye az L csatornán (jobb oldal)

2. táblázat.

ArUco-kód-keresés hatékonyságának növelése

\begin{tabular}{|l|r|r|r|r|r|}
\hline \multirow{2}{*}{ fáj1 } & \multicolumn{1}{|c|}{ képkocka } & \multicolumn{2}{c|}{ Alapalgoritmus } & \multicolumn{2}{c|}{ L csatorna hisztog. } \\
\cline { 2 - 6 } & \multicolumn{1}{|c|}{ szám } & találat & \multicolumn{1}{c|}{$\%$} & \multicolumn{1}{c|}{ találat } & \multicolumn{1}{c|}{$\%$} \\
\hline 3_20191207_105813.h264 & 3452 & 1965 & 56,9 & 3146 & 91,1 \\
\hline 4_20191207_103907.h264 & 4167 & 1801 & 43,2 & 3541 & 85,0 \\
\hline 5_20191207_114801.h264 & 15790 & 13556 & 85,9 & 13882 & 87,9 \\
\hline 5_20191209_143236.h264 & 13500 & 7856 & 58,2 & 10925 & 80,9 \\
\hline 5_20191211_103149.h264 & 4068 & 1945 & 47,8 & 3910 & 96,1 \\
\hline 5_20191211_153508.h264 & 5448 & 3663 & 67,2 & 4074 & 74,8 \\
\hline 4_20191213_120446.h264 & 13532 & 10141 & 74,9 & 12917 & 95,5 \\
\hline 4_20191213_135821.h264 & 16117 & 15552 & 96,5 & 15906 & 98,7 \\
\hline 5_20191213_140133.h264 & 15722 & 12698 & 80,8 & 14040 & 89,3 \\
\hline 4_20191214_115855.h264 & 15877 & 14878 & 93,7 & 15752 & 99,2 \\
\hline
\end{tabular}
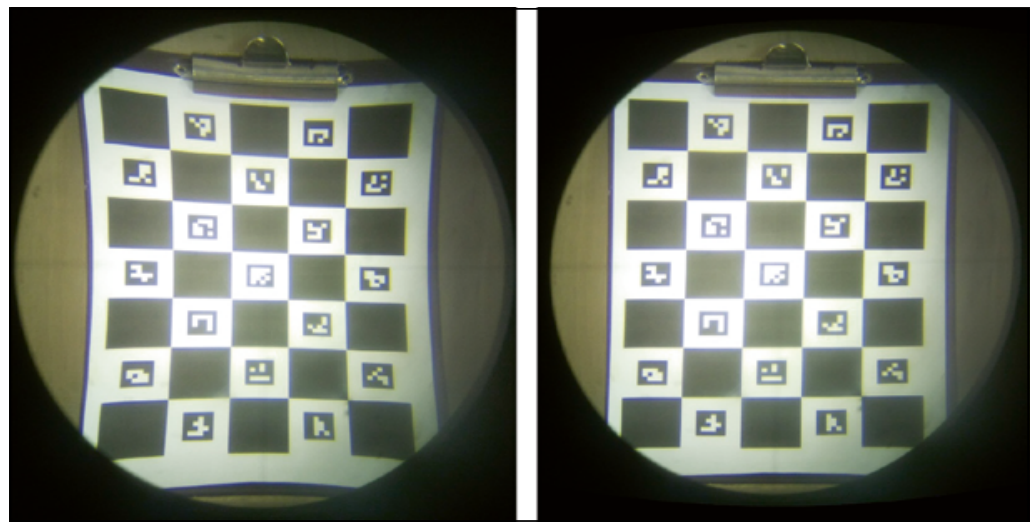

6. ábra. A kamera + a geodéziai távcsố nyers képe (bal oldal) és a kalibráció paramétereivel javított változat (jobb oldal)

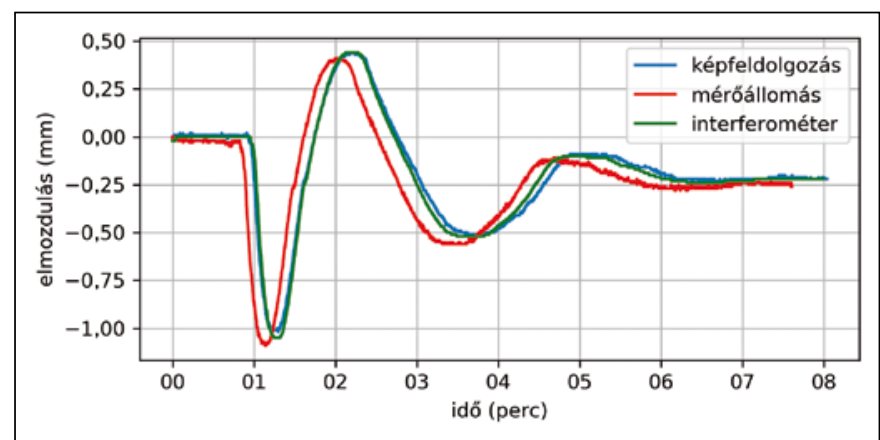

7. ábra. A Rákóczi híd dinamikus próbaterhelése során, a saru vízszintes elmozdulása méróálllomással, képfeldolgozással és interferométerrel meghatározva

\section{Alkalmazási tapasztalatok}

Az elsô, 2015-ös kísérleti alkalmazás során három technológiát alkalmaztunk a hídzsámolyon a dinamikus terhelés hatására történó elmozdulás meghatározására, a képfeldolgozás mellett interferométert és robotmérôállomást is, mivel a technológia alkalmazhatóságának az igazolása volt a célunk. A nagy tömegú teherautó hirtelen fékezése hatására lezajló mozgást a képfeldolgozásból is nagy pontossággal meg tudtuk határozni (7. ábra). Ebben az esetben mikroszkópkamerát (Dino-Lite Pro AM4000) és laptopot használtunk a terepen.

2019.decemberében egy úszómú statikus próbaterhelése során alkalmaztuk a továbbfejlesztett hardver-és szoftvermegoldásunkat, számos más szenzorral együtt. Az úszómún a folyó hullámzásának kimutatására három ArUco-jelet $(72 \times 72 \mathrm{~mm})$ helyeztünk el, így feldolgozás során mindkét módszert (sablonkeresés és ArUcokód-felismerés) alkalmazni tudtuk. A három ArUco-jelet egy-egy Leica méróállomásra szerelt Raspberry Pi V2 kamerával vettük fel, másodpercenként két kép frekvenciával. Emellett három GNSS-vevôvel és két robot-mérôállomással is végeztünk észleléseket. A próbaterhelés során $30 \mathrm{~cm}$ körüli magasságváltozások voltak várhatók. A kamerás (2 Hz) és a GNSS- (1 Hz) észlelések egy-egy teherállás során folyamatosan történtek. A robot-mérôállomással csak a kezdô és végállapotban végeztünk méréseket (8. ábra)

A képfeldolgozáson alapuló megoldáshoz használt eszközök jóval kisebb költséget jelentenek a hagyományos geodéziai eszközökhöz képest. A mérési eredmények megbízhatósága a GNSS-technikáénál nagyobb. Kis távolságon (pár méter) a méróállomásnál pontosabb, néhány tíz méteres távolságon ahhoz közelítő eredményt kaphatunk. Az alkalmazott hardver függvényében a gyakoribb mintavételezésre alkalmas, így gyorsan lezajló mozgások, deformációk megfigyelésére is lehetôséget biztosít. A módszernek persze vannak hátrányai is a GNSS- vagy robot-méróállomás 

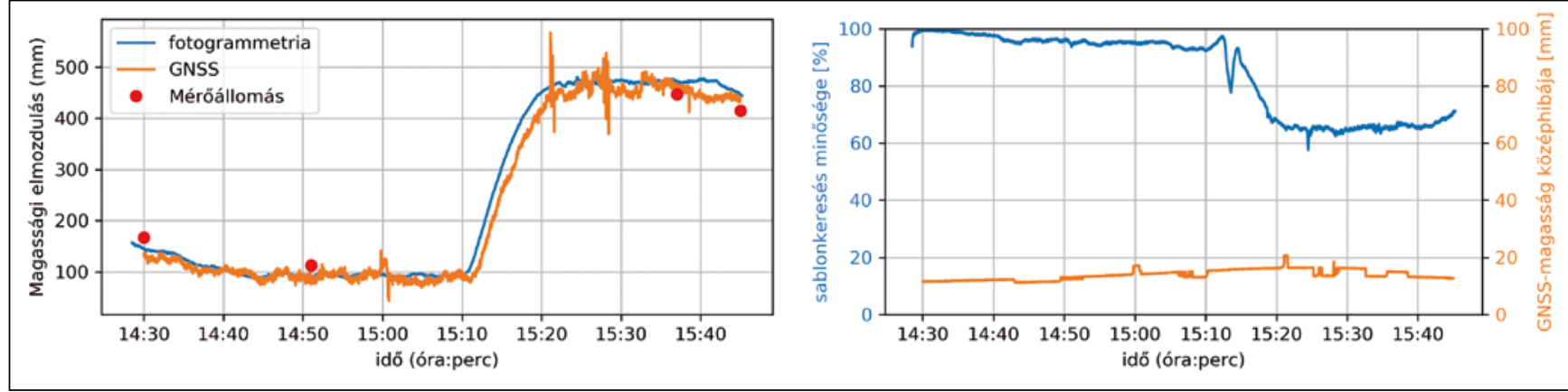

8. ábra. Az úszómú statikus próbaterhelése során meghatározott magassági elmozdulások fotogrammetriával, GNSS-technikával és mérốállomással

alkalmazásával szemben: csak 2D-ben, azaz a képsíkkal párhuzamos síkban ad eredményt, csak relatív adatok meghatározására alkalmas, a kép méretének függvényében csak meghatározott mértékú elmozdulás kimutatása lehetséges, és sötétben nem használható.

\section{Fejlesztési perspektívák}

Bár már most is gyakorlati feladatok során alkalmazható rendszert sikerült összeállítanunk, mind a hardver, mind a szoftver területén több fejlesztési lehetôséget igyekszünk a jövôben megvalósítani. A hardverkialakítás még nem teljesen időjárásálló, a távcsôre rögzítést lehetôvé tevô adapter mellett esố elleni védelmet kell kialakítani a Raspberry Pi kamerához. A parallaxis eltüntetése nem egyszerú feladat a távcsốre felszerelt kamerával. A terepen általában nem kapcsolunk közvetlenül egy képernyốt a Raspberry Pi számítógéphez, mert például nincs megfelelô energiaforrás ehhez. Ebben az esetben egy mobileszközrôl (telefon, tablet, laptop) csatlakozunk a Raspberry Pi-hez és a WIFI-hálózaton keresztül visszük át a videóképet a két eszköz között. A lassú WIFI-adatátvitel miatt akár 10-20 másodperc késleltetéssel jelenik meg a külsố eszköz képernyőjén a kamerakép. Ez körülményessé teszi a beállítást.

Jelenleg a Raspberry Pi számítógép által rögzíthetô képek másodpercenkénti számát (fps) elsôsorban a SD-kártya sebessége határozza meg. A jelenlegi kiépítésben ez nagyjából 2 fps, ami gyorsan lezajló jelenségek megfigyelésére nem alkalmas. Itt a gyorsításhoz számos kész megoldás szóba jöhet, mint például a kis fogyasztású SSD-háttértároló, nagyobb teljesítményú mini PC, esetleg terepálló laptop alkalmazása.

A gyorsabb hardver esetén az online feldolgozás is lehetôvé válhat, amikor a videórögzítés nem feltétlenül szükséges. A programokat már alkalmassá tettük az online feldolgozásra. Egy nem nagy teljesítményú laptoppal (Intel(R) Core(TM) i7-8565U CPU @ 1.80GHz, 8 GB RAM) másodpercenként $10 \mathrm{fel}$ vétel online feldolgozását tudtuk elvégezni a sablonkeresés módszerével. További gyorsítás érhetô el a többszálas programozással és a GPU számítási célokra történô felhasználásával.

Eddig nem használtuk ki, hogy az ArUco-kódok keresése során lehetôség van a jelhez kapcsolt térbeli koordinátarendszer-tengelyelfordulásainak meghatározására is. Ez fóként deformációvizsgálat esetén jelentene többletinformációt. Jelenleg képenként egy ArUco-jel megkeresését valósítja meg a program. Egy másik fejlesztési irány lehet, hogy egy képkockán több jel felismerését és megkeresését is támogassa az alkalmazás.

\section{Köszönetnyilvánítás}

A szerzôk köszönetet mondanak az EMMI-nek a BME FIKP-VIZ pályázat keretében nyújtott támogatásért.

\section{Irodalom}

Engel, P. - Schweimler, B. 2016. Development of an Open-Source Automatic Deformation Monitoring System for Geodetical and Geotechnical Measurements, ISPRS Journal of Photogrammetry and Remote Sensing XL-5/W8.25-30,

DOI: 10.5194/isprs-archives-XL-5-W8-25-2016 Kis Papp, L. 1965. Az Erzsébet híd mozgásának vizsgálata fotogrammetriai módszerrel. Geodézia és Kartográfia 17. évf. 3. sz. pp. 187-195.

Kovács, N. - Kövesdi, B. - Dunai, L. - Takács, B. 2016. Loading Test of the Rákóczi Danube

Bridge in Budapest. Procedia Engineering, Volume 15, 2016, pp. 191-198. DOI: $10.1016 /$ i.proeng. 2016.08.286

OpenCV Tutorials (é. n.). https://docs.opencv. org/master/d9/df8/tutorial_root.html utolsó elérés: 2020. 12. 27.

Paulik, D. - Tóth, M. T. - Molnár, B. Neuberger, H. - Horváth, L. 2018. Mérnökfotogrammetriai támogatás a tartószerkezetek vizsgálatához. Geodézia és Kartográfia, 70. évf. 2. sz. pp. 15-20. DOI: $10.30921 / \mathrm{GK} .70 .2018 .2 .2$

Simonot, L. - Hébert, M. - Dupraz, D. 2011. Goniocolorimetry: From Measurement to Representation in the CIELAB Color Space. Color Research \& Application 36. évf. 3. sz. DOI: $10.1002 / \mathrm{col} .20605$

Siki, Z. - Takács, B. - Égetô, Cs. 2018. Ulyxes and open source project for automation in engineering surveying. Peerj Preprints. 6 Paper e27226v1 DOI: $10.7287 /$ peerj.preprints.27226v1

Villán, A. F. 2019. Mastering OpenCV 4 with Python. PackPub. ISBN 978-1-78934-491-2

Briechle, K. - Hanebeck, U. D. 2001. Template matching using fast normalized cross correlation. Proceedings of SPIE The International Society for Optical Engineering 4387, 2001 March DOI: $10.1117 / 12.421129$

Völgyesi, L. - Tóth, Gy. 2020. Calibration of CCD sensors mounted on geodetic measuring system, Surveying Review 52. évf. pp. 1-10. DOI: $\underline{10.1080 / 00396265.2019 .1703506}$

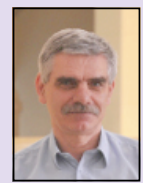

Dr. Siki Zoltán egyetemi adjunktus

BME Általános és Felsőgeodézia Tanszék siki.zoltan@epito.bme.hu

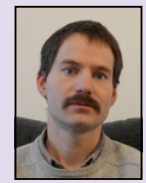

Dr. Takács Bence egyetemi docens

BME Általános és Felsốgeodézia Tanszék takacs.bence@epito.bme.hu 